\title{
The Relationship between Vocabulary Knowledge and Speech Perception in School-Age Children using Cochlear Implants
}

\author{
Hye-Jin Park ${ }^{\mathrm{a}}$, Sung-Ah Han ${ }^{\mathrm{a}}$, Jae-Hee Choi ${ }^{\mathrm{a}}$, Sang-Yong Sim ${ }^{\mathrm{a}, \mathrm{b}}$, Young-Ran Seo ${ }^{\mathrm{c}}$, Hyun-Sook Jang ${ }^{\mathrm{d}}$ \\ ${ }^{a}$ Department of Speech Pathology and Audiology, Graduate School, Hallym University, Chuncheon, Korea \\ ${ }^{b}$ Dasan Auditory Rehabilitation Lab, Seoul, Korea \\ 'Kyungshin Auditory Rehabilitation Center, Daegue, Korea \\ ${ }^{d}$ Division of Speech Pathology and Audiology, Hallym University, Chuncheon, Korea
}

Correspondence: Hyun-Sook Jang, $\mathrm{PhD}$

Division of Speech Pathology and Audiology, Hallym University, 1 Hallimdaehak-gil, Chuncheon 24252, Korea

Tel: +82-33-248-2218

Fax: +82-33-256-3420

E-mail: hsjang@hallym.ac.kr

Received: July 5, 2016

Revised: August 31, 2016

Accepted: September 8, 2016
Objectives: The purpose of this study was to investigate the relationship between receptive vocabulary knowledge and speech perception ability in children with cochlear implant (Cl) after assessing vocabulary knowledge in terms of chronological and hearing age, and speech perception ability at the sentence and discourse levels. Methods: This study included 25 children with $\mathrm{Cl}$ who received their first $\mathrm{Cl}$ before the age of 6 , had used $\mathrm{Cls}$ more than $6 ; 6$ years, had no other disabilities, and were attending regular elementary or secondary schools. Receptive vocabulary knowledge and speech perception ability were assessed with the REVT (Receptive \& Expressive Vocabulary Test) and 3 subtests of KNISE-DASP (Korean National Institute of Special Education-Development Assessment of Speech Perception), Sentence Comprehension Test, Sentence Recognition Test, and Connected Speech Test. Correlation analysis was also conducted between speech perception and vocabulary. Results: The average REVT equivalent age of the $\mathrm{Cl}$ group was delayed for 1;10 years compared to the age-matched normal hearing peers, but was placed within the average range of normal hearing children when the hearing age was matched. The participants had some difficulties in speech perception, especially at the discourse level. The speech perception ability was highly correlated with vocabulary scores, but some students had difficulties in speech perception despite vocabulary knowledge comparable to their normal hearing peers. Conclusion: Difficulties in speech perception at the sentence and discourse levels could have resulted from a lack of vocabulary knowledge. The results suggest that aural rehabilitation programs should include treatment for the improvement of speech perception at the sentence and discourse levels.

Keywords: Hearing loss, Cochlear implant, Vocabulary, Speech perception, Sentence comprehension, Sentence recognition, Connected speech comprehension
언어능력의 발달은 언어를 전달하는 소리 정보 즉, 분절적인 특 성과 초분절적인 특성을 포함하고 있는 음향학적 연속체를 지각하 고 처리하는 듣기 기술의 발달을 통해 이루어진다(Cole \& Flexer, 2015). 특히 청각장애 아동의 경우, 듣기 기술의 발달 정도를 파악 하는 것은 그들의 언어 발달 및 학업 수행의 결과를 이해하고 필요 한 중재 목표를 설정하는 데 기초가 된다. 청각장애 아동의 구어발 달 및 학업 수행과 밀접한 관련이 있는 듣기 기술은 Erber (1982)의

\begin{abstract}
듣기 기술 발달 중 ‘이해’ 단계로 이 단계에서는 소리 정보의 의미를 처리하게 된다. 언어가 전달되는 속성상 이 단계의 듣기 기술은 청 각정보처리과정(auditory information processing)이면서 동시에 언어적처리과정(linguistic processing)의 성격을 지닌다. 따라서 '이 해' 단계의 듣기 기술은 상위 단계의 언어학적 단위인 연결 발화, 즉 담화 수준의 소리정보 처리까지 포함한다(Ling, 2002; Perigoe \& Paterson, 2013; Tye-Murray, 2014).
\end{abstract}


문장이나 대화, 담화 수준의 소리정보 처리는 학령기에서 점점 더 중요해지는데, 이러한 활동은 학교에서 매일 접하게 되는 듣기 상황이기 때문이다. 예를 들어 학교에서 수업 중 설명을 듣고 이해 하는 것, 교사의 지시사항이나 질문을 듣고 이해하는 것, 그리고 친 구들과의 대화를 듣고 이해하는 능력 등은 청각장애 아동의 학업 수행은 물론 의사소통 능력과 사회적 관계에까지 영향을 미친다. 따라서 학교에서의 교과 과정이나 수업, 교사가 사용하는 지시문, 친구들과의 대화 등을 고려할 때, 문장 및 담화 수준에서의 청각적 정보를 이해하고 처리하는 말지각 능력은 학령기에 반드시 발달되 어야 하는 능력으로 평가나 중재의 목표로 포함되어야 한다(Kaplan, Mahshie, Moseley, Singer, \& Winston, 1993). 이를 반영하여 Auditory Skills Checklist (Anderson, 2004), Auditory Learning Guide (Walker, 2009), Auditory Skills Program (Romanik, 1994) 등의 청각 기술 평가나 중재 프로그램은 모두 청각장애 아동의 종 합적인 의사소통능력 평가의 한 요소로서 듣기 기술 발달의 최상 위 단계에 문장뿐 아니라 연결발화(connected speech), 즉 담화 수 준의 이해를 포함하고 있다.

인공와우 착용 아동의 말지각 능력은 다양한 변수들에 의해 영 향을 받으므로 그 결과가 개인에 따라 매우 다양하게 나타날 수 있 지만, 일반적으로 이식시기가 빠를수록 그 수행력이 높고, 착용기 간이 증가할수록 말지각 능력이 지속적으로 발달되며, 많은 경우 정상적인 발달 수준까지 향상을 보인다(Hyun \& Yim, 2013; Niparko et al., 2010). 또한 청각학적인 변인들 외에 인공와우 착용 아동 의 말지각 수행력에 영향을 미치는 중요한 변인 중 하나는 언어능 력으로, 말지각 능력과 수용 및 표현언어와는 높은 상관성이 있는 것으로 나타났다(Blamey et al., 2001; Blamey \& Sarant, 2002; Davidson, Geers, Blamey, Tobey, \& Brenner, 2011; Kang \& Ha, 2013; $\mathrm{Wu}$ et al., 2011). 예를 들어, $\mathrm{Wu}$ 등(2011)은 평균 3세경에 인공와우 를 이식받고 7-9년 정도의 착용기간을 가진 39명의 아동들이 문장 인지 검사에서 $78 \%$ 의 목표단어 정반응률을 보였으며, 검사점수와 표현 및 수용 언어점수와의 높은 상관성을 보였다고 보고하였다.

어휘력과 단어 및 문장의 말지각 수행과의 관계에 대한 장기 추 적 연구(Blamey et al., 2001; Blamey \& Sarant, 2002; Davidson et al., 2011)에서 어휘력이 발달하는 동안 말지각 수행력에 연령에 따 른 증가가 나타나며, 어휘력 검사(PPVT)에서 각각 등가연령 7, 10 세 수준의 어휘력을 보일 때 단어와 문장 지각 수행에서 고원현상 을 보이며 더 크게 향상되지 않음을 보고하였다. 이러한 연구 결과 들은 단어와 문장 수준의 말지각 수행력이 어휘력과 관계가 있으 며, 또한 말지각의 수행 향상이 어휘력으로 대표되는 언어발달 정 도를 반영하는 것임을 입증한다.
학령기 청각장애 아동의 어휘력은 청각보조기기가 상대적으로 덜 발달했던 과거에 비해 최근 매우 향상되었으나, 연구에 따라 그 결과가 매우 상이하다. 예를 들어 학령기 아동의 어휘력을 보고한 연구 결과를 보면 2-5세 사이에 인공와우 수술을 한 경우 약 50\%$57 \%$ 의 아동들이 수용어휘에서 건청 또래 기준 $1 \mathrm{SD}$ 이내의 수행을 보인다는 결과(Boons et al., 2013; Duchesne, Sutton, \& Bergeron, 2009; Geers, Moog, Biedenstein, Brenner, \& Hayes, 2009)와 약 2-4 년 사이의 지체를 보인다는 연구 결과가 공존한다(Fagan \& Pisoni, 2010; Johnson \& Goswami, 2010). 그러나 Fagan과 Pisoni (2010), 그리고 Thal, DesJardin과 Eisenberg (2007)는 인공와우 착용 아동 들의 어휘력이 듣기연령(hearing age)과 생활연령을 일치시킨 건청 아동의 어휘력 검사 결과 평균 범위에 해당한다고 보고하였다. 인 공와우를 이식 받는 경우는 고심도 난청으로 보청기를 착용하여도 말소리 지각에 제한이 있으므로, 이 논문에서 듣기연령은 인공와 우 이식 후 말소리 지각에 필요한 주파수들을 듣게 되는 '생활연령인공와우 사용 시작 연령'으로 계산하였다. 이 선행연구들은 비록 인공와우 착용 아동들의 어휘력이 생활연령에 비해 지체되어 있으 나, 그들의 듣기연령, 즉 청각적으로 정보를 접한 기간에 비례하여 발달하고 있음을 시사한다.

인공와우 착용 아동을 대상으로 한 어휘력 연구 결과를 종합하 면 또래 건청 아동에 비해 어휘의 양이 적을 뿐 아니라 어휘발달 속 도 또한 뒤처지며(Fagan \& Pisoni, 2010; Holt, Beer, Kronenberger, Pisoni, \& Lalonde, 2012; Quittner et al., 2013), 연령이 증가할수록 어휘 습득 속도가 느려지고(Blamey, Bow, Paatsch, Sarant, \& Galvin, 2004; Convertino, Borgna, Marschark, \& Durkin, 2014), 어휘 량이나 습득 속도 모두에 큰 개인차가 존재한다(Hayes, Geers, Treiman, \& Moog, 2009; Pisoni, Kronenberger, Roman, \& Geers, 2011) 고 보고되고 있다. 느린 어휘발달 속도는 인공와우 착용 아동의 어 휘발달 지체가 지속되게 할 뿐 아니라 아동이 성장할수록 건청 아 동의 어휘량과 비교했을 때 그 차이가 점점 더 커지는 데 영향을 미 친다(Hayes et al., 2009).

그 외 일반적으로 건청 또래에 비해 뒤떨어지는 언어능력이나 읽 기능력이 아동들의 어휘력 발달에 부정적인 영향을 미치는 것으로 간주되고 있다. 정상청력 아동들의 경우 부모나 의사소통 파트너와 의 상호작용을 통해, 그리고 TV와 라디오에서의 말하는 단어나 다 른 사람들의 대화를 우연히 들음(overhearing)으로서 새로운 어휘 를 습득한다. 그러나 청각장애 아동들은 이러한 듣기가 어려워 새 로운 어휘나 구문을 다양한 맥락에서 우연학습을 할 기회가 매우 적거나 없다. 또한 상대적으로 뒤떨어진 읽기 능력으로 인해, 읽기 를 통해 새로운 어휘나 언어능력을 습득하는 데 제한적이 될 수 있 
다(Traxler, 2000). 읽기 능력은 구어능력(spoken language ability) 을 기반으로 한 문자의 음운론적 해독으로 설명할 수 있는데, 이 때 담화수준의 구어 능력이 읽기 발달과 가장 관련이 있다. 담화 수준 의 구어능력은 담화 수준의 소리정보 처리 능력을 바탕으로 발달 한다는 점에서 이 단계에서의 듣기기술 발달의 중요성을 다시 한 번 확인할 수 있다. 그러나 이렇듯 담화 수준에서의 소리정보 처리 의 중요성이 강조되고 있음에도 불구하고 국내 학령기 청각장애 아동의 듣기기술 발달 연구는 주로 음소와 단어, 문장 수준 위주로 이루어지고 있으며(Heo, Ahn, \& Boo, 2011; Kim, Lee, Heo, \& Oh, 2002; Kim, Kim, Cho, \& Rhee, 1998), 담화 수준에서의 수행 능력 을 보고한 연구는 없는 실정이다.

현재 인공와우를 착용하는 고심도 청각장애 아동 수가 증가하 고 있고, 그들의 대부분이 일반학교에 통합되어 교육받고 있다. 이 러한 통합환경에 배치된 인공와우 착용 아동들이 성공적으로 학 업, 의사소통 및 사회성 발달을 이루기 위해서는 정상발달 수준의 어휘력과 문장 및 담화 수준에서의 청각적 정보를 이해하고 처리 하는 말지각 능력을 갖추도록 지속적인 지원이 필요하다. 그러나 국내 통합환경의 학령기 인공와우 착용 아동의 어휘력과 문장 및 담화 수준의 말지각 발달에 대한 연구가 거의 이루어지지 않아 교 육적 및 재활적 요구를 모색하기에는 제한적인 실정이다. 이에 본 연구는 인공와우를 사용하고 있는 학령기 청각장애 아동을 대상 으로 생활연령과 듣기연령에 따른 (1) 수용어휘 발달 정도, (2) 보기 없이 청각적 단서만 제시되는 문장 및 담화 수준에서 말지각 수행 력, 그리고 (3) 말지각 수행력과 수용어휘력 간의 상관성를 파악하 고자 하였다. 특히 말지각 수행력의 경우 연령, 어휘력, 인공와우 이 식시기의 각 변인에 따라 두 집단으로 나누어 수행력의 차이를 비 교하였다.

\section{연구 방법}

\section{연구대상}

본 연구는 서울과 대구 및 강원도에 소재한 일반학교에 통합된 인공와우 착용 학생으로 초등학생 12 명과 중고등학생 13 명 총 25 명(남: 15 명, 여: 10명)을 대상으로 하였다. 연구대상자의 평균 연령 은 151.04 (SD = 31.27)개월, 연령 범위는 96-206 (8;0-17;2)개월이었 다. 모든 대상자들은 (1) 선천적 난청 또는 언어습득 이전에 난청이 있고, (2) 6세 이전에 첫 번째 인공와우 시술을 받았고, (3) 인공와우 착용기간이 6년 이상 경과되었으며, (4) 의사소통 방식으로 구화를 사용하고, (5) 일반학교에서 통합교육을 받고, (6) 청각장애 이외에 는 동반장애가 없었다. 첫 번째 인공와우를 이식한 평균 연령은
$28.12(\mathrm{SD}=15.82)$ 개월이었으며, 가장 빠른 연령은 12 개월, 가장 늦 은 연령은 71 개월이었다. 연구 참여자들의 평균 듣기연령(인공와우 로 소리를 접한 기간)은 114.84 ( $\mathrm{SD}=34.98)$ 개월로 그 범위는 78162 개월이었다. 자료 수집은 서울과 대구의 청각재활 기관과 강원 도 소재 대학의 청각언어센터에서 자격을 갖춘 청능사와 언어재활 사에 의해 이루어졌으며, 연구대상자의 성별, 학교, 연령, 인공와우 시술연령, 듣기연령, 인공와우 사용 후 교정 청력, 인공와우 착용상 황, 청능재활 여부에 대한 정보는 Table 1과 같다.

\section{연구자료}

어휘력 검사

연구대상자들의 어휘력을 평가하기 위해 수용 및 표현 어휘력검 사(REVT; Kim, Hong, Kim, Jang, \& Lee, 2009)의 수용어휘검사를 실시하였다. REVT는 규준 참조검사로 2세부터 성인에 이르기까지 원점수의 연령별 규준을 제시하고 있어 초등 및 중고등학교에 재학 중인 본 연구대상자 어휘력의 정상정 여부를 파악할 수 있다. 원점 수는 등가월령 또는 등가연령으로 환산될 수 있는데 본 연구에서 는 언어발달 지체 정도를 파악하기 위해 원점수를 등가월령으로 환산하여 자료 분석에 사용하였다.

\section{말지각 검사}

문장과 담화 수준의 말지각 능력을 평가하기 위해 KNISE-DASP (DASP; Song, Lee, \& Jang, 2010)의 하위 검사인 문장이해검사(Sentence Comprehension Test, SCT), 문장인지검사(Sentence Recognition Test, SRT), 그리고 이야기 이해검사(Connected Speech Test, $\mathrm{CST}$ )를 이용하였다. DASP은 학령기인 청각장애 아동의 말지각 능 력을 평가하기 위한 규준 참조검사로, 유치부-초등학교 저학년 수준 의 고빈도 어휘와 구문을 사용하여 검사 대상 아동의 어휘 및 언어 능력이 말지각 능력에 미치는 영향을 최소화하였고, 1,227 명의 유 치원과 초등학교에 재학중인 건청 아동을 대상으로 표준화되었다.

$\mathrm{DASP}$ 의 SCT, SRT, CST는 보기가 있는 조건(closed-set)과 보기 가 없는 조건(open-set)에서 말지각에 청각과 시각 단서를 모두 사 용하는(auditory visual) 조건과 시각적 단서를 배제하고 청각적 자 극만 사용하는(auditory only) 조건의 검사 방법을 포함하고 있는 데, 본 연구에서는 3 개의 검사 모두 보기 없이 청각적 자극만을 사 용하는 조건의 말지각을 검사하였다. SCT와 SRT는 모두 문장 수 준의 말지각 검사이다. SCT는 아동이 문장을 듣고 그에 맞게 한 단 어로 답을 하는 방식이고, 모두 10 개의 문장으로 구성되어 있으며, 아동이 정반응한 문장의 수의 총점이 원점수이다. SRT는 검사자가 제시한 문장을 듣고 아동이 그대로 따라말하는 방식으로, 모두 10 
Table 1. Demographic information of the participants

\begin{tabular}{|c|c|c|c|c|c|c|c|c|}
\hline Subject no\# & Gender & School & $\begin{array}{c}\text { CA } \\
\text { (mo) }\end{array}$ & $\begin{array}{c}\text { Age at } \mathrm{Cl} \\
\text { (mo) }\end{array}$ & $\begin{array}{l}\text { Hearing age } \\
\text { (mo) }\end{array}$ & $\begin{array}{l}\text { PTA with Cl } \\
\text { (dB) }\end{array}$ & $\begin{array}{c}\text { Hearing } \\
\text { device use }\end{array}$ & $\mathrm{AR}$ \\
\hline 1 & $\mathrm{~F}$ & $E$ & 96 & 18 & 78 & 30 & Unilateral & Yes \\
\hline 2 & $M$ & $E$ & 97 & 18 & 79 & 28 & Unilateral & Yes \\
\hline 3 & $\mathrm{M}$ & $\mathrm{E}$ & 111 & 18 & 93 & 25 & Bilateral & No \\
\hline 4 & $M$ & $E$ & 114 & 12 & 102 & 31 & Unilateral & Yes \\
\hline 5 & M & E & 116 & 24 & 92 & 35 & Bilateral & Yes \\
\hline 6 & $\mathrm{~F}$ & $E$ & 117 & 13 & 100 & 33 & Unilateral & Yes \\
\hline 7 & $M$ & $E$ & 127 & 42 & 85 & 26 & Unilateral & No \\
\hline 8 & $M$ & $E$ & 132 & 15 & 118 & 34 & Bimodal & Yes \\
\hline 9 & $\mathrm{~F}$ & $E$ & 137 & 12 & 126 & 23 & Unilateral & Yes \\
\hline 10 & $\mathrm{~F}$ & $E$ & 146 & 24 & 119 & 33 & Unilateral & Yes \\
\hline 11 & $\mathrm{M}$ & $E$ & 150 & 36 & 114 & 30 & Unilateral & No \\
\hline 12 & $M$ & $E$ & 153 & 44 & 109 & 13 & Bimodal & Yes \\
\hline 13 & $\mathrm{~F}$ & S & 157 & 33 & 124 & 36 & Bilateral & Yes \\
\hline 14 & M & S & 157 & 20 & 142 & 35 & Bimodal & Yes \\
\hline 15 & $\mathrm{M}$ & $S$ & 159 & 48 & 111 & 26 & Bimodal & No \\
\hline 16 & $\mathrm{~F}$ & $S$ & 161 & 71 & 91 & 24 & Unilateral & Yes \\
\hline 17 & $\mathrm{~F}$ & S & 168 & 18 & 150 & 31 & Unilateral & Yes \\
\hline 18 & $M$ & S & 168 & 38 & 133 & 36 & Bimodal & Yes \\
\hline 19 & $F$ & S & 169 & 24 & 145 & 25 & Bilateral & Yes \\
\hline 20 & $\mathrm{~F}$ & S & 171 & 18 & 153 & 22 & Bilateral & No \\
\hline 21 & $\mathrm{M}$ & $S$ & 187 & 30 & 157 & 40 & Bimodal & Yes \\
\hline 22 & $M$ & S & 188 & 48 & 140 & 25 & Bimodal & Yes \\
\hline 23 & M & $S$ & 193 & 31 & 162 & 28 & Bilateral & Yes \\
\hline 24 & $M$ & $S$ & 196 & 48 & 148 & 35 & Bimodal & Yes \\
\hline 25 & $\mathrm{~F}$ & S & 206 & 60 & 146 & 30 & Unilateral & No \\
\hline
\end{tabular}

$\mathrm{E}=$ elementary school; $\mathrm{S}=$ secondary school; $\mathrm{F}=$ female; $\mathrm{M}=$ male; $\mathrm{CA}=$ chronological age; $\mathrm{Cl}=$ cochlear implant; age at $\mathrm{Cl}=$ age at the first $\mathrm{Cl}$ switch on; Unilateral=use only one $\mathrm{Cl}$; Bimodal = use one $\mathrm{Cl}$ and one $\mathrm{HA}$ at the other side of ear simultaneously; Bilateral = use two $\mathrm{Cls}$; $\mathrm{PTA}=$ pure-tone threshold average at 500, 1,000, and 2,000 Hz; $\mathrm{AR}=$ enrollment in the aural rehabilitation program at the time of the test.

개 문장에 40 개의 목표단어로 구성되어 있다. 10 개 문장의 평균 문 장 길이는 4어절, 범위는 2-6개 어절이다. 아동이 따라 말한 문장에 서 목표단어의 정반응 개수를 합산하여 원점수를 구한다. SCT는 2 개부터 6개까지의 문장으로 구성된 이야기를 들은 후 각 이야기에 대한 질문에 답하는 방식의 검사로 각 이야기마다 1-2개의 질문으 로 구성되어 있다. 세 검사 모두 원점수를 백분율로 환산하여 분석 에사용하였다.

\section{연구 절차}

자격을 갖춘 언어재활사와 청능사가 조용한 방에서 아동과 일대 일로 앉아 각각 REVT와 DASP를 실시하였다. REVT와 DASP 검 사를 할 때 아동과 검사자와의 거리는 약 $1 \mathrm{~m}$ 였다. REVT는 아동이 검사자의 얼굴을 볼 수 있는 상태에서 검사 지침서에 따라 검사를 진행하였다. 아동이 원할 경우 검사 문항을 글씨로 써서 보여주었으 며, 육성과 글씨를 포함하여 최대한 2 번까지 검사 문항을 제시하였
다. DASP의 검사 문항은 아동이 검사자의 얼굴을 볼 수 없는 상태 에서 검사자의 육성으로 제시하였고, 검사는 SRT, SCT, CST의 순 으로 진행하였다. 어휘력 검사와 말지각 검사는 대부분 서로 다른 날 시행하였으며, 동일한 날 진행할 경우 두 검사 사이에 아동이 충 분히 쉴 수 있도록 하였고, 두 검사의 순서는 번갈아서 진행하였다.

\section{자료 분석}

어휘력검사 결과는 두 가지 방법으로 분석하였다. 첫째, REVT 검사지침서의 '연령별 수용 및 표현어휘 점수의 평균 및 표준편차' 를 이용하여 검사대상자의 어휘발달 정상성을 판별하고, 검사지침 서에 따라 그 결과를 정상발달(-1 SD 이상), 약간 지체(-1 SD와 -2 $\mathrm{SD}$ 사이), 어휘능력 발달지체(-2 SD 이하)로 분류하였다. 이때 청각 장애의 특성을 고려하여, 검사대상자의 생활연령(CA)과 듣기연령 $(\mathrm{HA})$ 을 기준으로 각각 어휘발달 정상성을 분석하여 그 결과를 백 분율로 제시하였다. 둘째, REVT 검사지침서의 '등가연령 규준표' 
에 따라 원점수를 등가월령으로 변환하여 어휘능력 발달지체가 어 느 정도 되는지 살펴 보았다. 어휘능력의 발달지체 분석도 역시 생 활연령과 듣기연령을 기준으로 각각 분석하였다. 검사대상자의 어 휘능력이 정상청력인 규준의 어휘발달에 비해 어느 정도 지체되는 지 알아보기 위해 지침서에서 제공한 등가월령과 생활연령 사이의 차이(등가월령-생활연령, 이하 EA-CA)를 구하여 분석에 사용하였 다. 또한 듣기연령을 기준으로 했을 때 동일한 듣기 경험을 가진 정 상청력 규준의 어휘발달에 비해 어느 정도 지체되는지 알아보기 위해 등가월령과 듣기연령 사이의 차이(등가월령-듣기연령, 이하 EA-HA)를 구하여 분석에 사용하였다.

말지각 검사 결과는 DASP의 SCT, SRT, CST 검사 각각의 정반 응률 평균과 표준편차를 구하였으며, 이를 연령별(초등과 중고등), 어휘력 발달별(정상집단과 지체집단), 이식연령별(2세 이전과 이 후)로 구분하여 각 집단의 평균의 차이를 $t$-검증하였다. 그리고 생 활연령과 듣기연령으로 나누어 연령과 각 검사에서의 수행결과와 의 상관관계를 분석하였다.

또한 마지막으로 어휘력과 말지각 능력과의 상관관계를 보기 위 해 REVT의 등가연령과 SRT, SCT, CST의 정반응률 간의 상관관계 를 분석하였다. 통계분석은 IBM사의 SPSS 23.0 을 사용하였다.

\section{연구 결과}

\section{어휘력 검사 결과}

검사대상자의 생활연령을 기준으로 어휘발달 정상성 여부를 분 석한 결과, 연구대상자 25 명 중 12 명(48\%)이 -1 SD 이상에 해당하 는 점수를 획득하여 어휘력이 '정상발달'로 나타났다. 그러나 2명 (8\%)은 '약간 지체,' 11 명(44\%)은 ‘어휘능력 발달지체’로 판정되었
다. 검사대상자의 듣기연령을 기준으로 어휘능력 발달의 정상성을 판정하였을 때에는 25 명 중 14 명 $(56 \%)$ 이 듣기연령이 같은 정상청력 아동의 '정상발달' 범주에, 3 명(12\%)이 '약간 지체,' 8 명(32\%)이 ‘어 휘능력 발달지체'에 해당하는 것으로 판정되었다. 각 분석조건에서 아동들의 어휘력 분포의 비율은 Figure 1에 제시하였다.

각 검사대상자의 어휘력이 생활연령이나 듣기연령 규준보다 얼 마나 지체되어 있는지를 파악하기 위해 검사대상자들이 획득한 원 점수를 REVT의 검사지침서에 따라 등가월령(EA)으로 환산하였 다. 언어발달 정상성 판단 결과에 따른 생활연령 및 듣기연령을 기 준으로 한 규준과의 차이를 Figure 2에, 연령 및 어휘력간의 상관관 계는 Table 2에 제시하였다.

연구대상자의 어휘력(EA)은 집단에 관계없이 공통적으로 생활 연령이 증가함에 따라 증가하는 추세를 보였으나(Figure 2A), 통계 적으로 유의한 확률에는 도달하지 못하였다 $(r=.347, p=.089)$. 연구 대상자 전체 집단의 수용어휘 등가월령 평균은 $133.04(\mathrm{SD}=48.67)$ 개월(범위: 31-193개월)이었다. 생활연령을 기준으로 한 규준과 비 교하여 어휘력의 지체 정도를 확인하였을 때, 집단에 관계없이 생 활연령이 증가할수록 EA-CA의 차이가 더 커지는 추세를 보이는 것으로 나타났으나(Figure 2B), 통계적으로 유의하지는 않았다 $(r=$ -.300, $p=.145)$. 본 연구대상자들의 EA-CA 평균은 $-18.00(\mathrm{SD}=47.86)$ 개월(범위: -142-45개월)로, 생활연령이 같은 REVT 검사지침서의 규준보다 어휘력에서 집단 평균 약 1 년 6 개월 정도의 지체를 보였 다. 생활연령보다 등가월령이 낮은 경우 EA-CA의 범위는 - 1 부터 -150 로 나타났다. 그리고 EA-CA는 인공와우 이식연령과 부적 상 관이 있었다 $(r=-.528, p=.007$ ) (Figure 2C).

듣기연령을 기준으로 했을 때, 연구대상자의 REVT EA는 듣기연 령의 증가와 유의한 관계가 있는 것으로 나타났다 $(r=.508, p=.009)$.
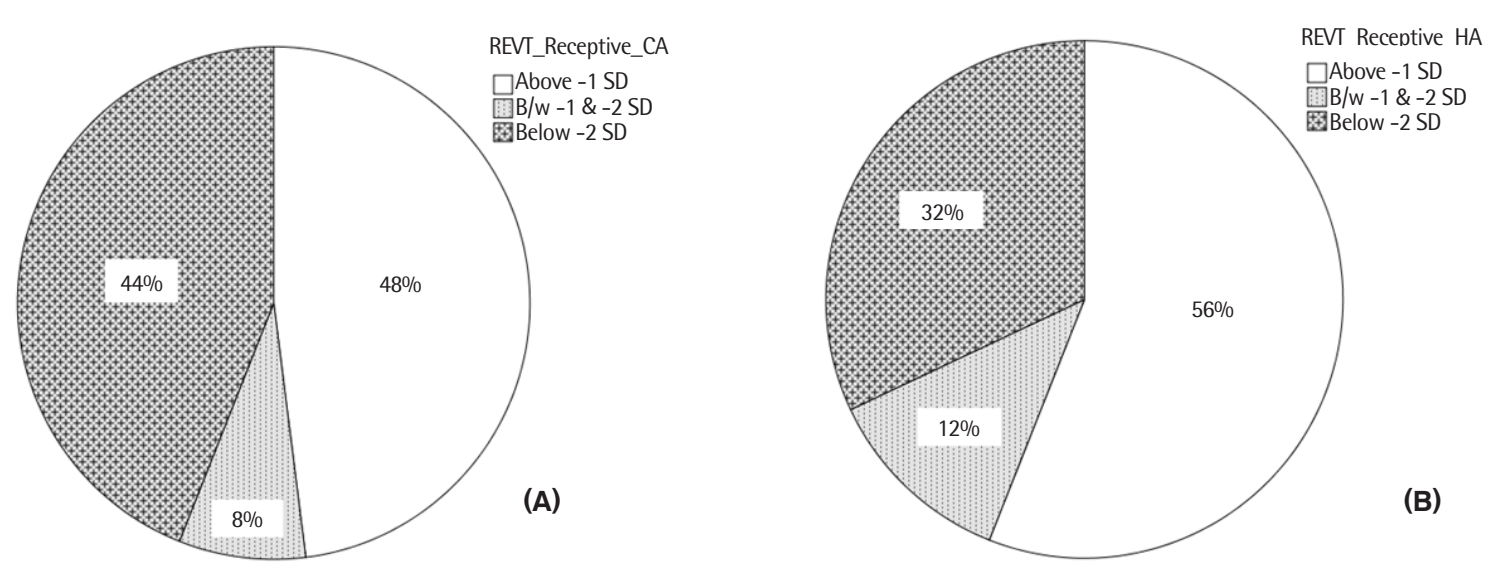

Figure 1. REVT_receptive vocabulary test outcomes as a function of (A) chronological age (CA), and (B) hearing age (HA). REVT=Receptive \& Expressive Vocabulary Test (Kim, Hong, Kim, Jang, \& Lee, 2009). 
그러나 듣기연령을 기준으로 REVT 규준과의 차이를 파악했을 때, $\mathrm{EA}-\mathrm{HA}$ 는 듣기연령과 관계가 없었으며 $(r=-.031, p=.882)$ (Figure $2 \mathrm{D})$, 인공와우 이식연령과도 상관관계가 없었다 $(r=-.154, p=.463)$.

Table 2. Correlations between age factors and vocabulary converted scores

\begin{tabular}{lccclll}
\hline & \multirow{2}{*}{ CA } & \multirow{2}{*}{ HA } & \multirow{2}{*}{ Age at Cl } & \multicolumn{3}{c}{ REVT } \\
\cline { 5 - 7 } & & & & EA & EA-CA & EA-HA \\
\hline CA & - & $.863^{* *}$ & $.569^{* *}$ & .347 & -.300 & -.133 \\
HA & & - & .079 & $.508^{* *}$ & -.047 & -.031 \\
Age at Cl & & & - & -.154 & $-.528^{* *}$ & -.227 \\
\hline
\end{tabular}

$\mathrm{CA}=$ chronological age; $\mathrm{HA}=$ hearing age; $\mathrm{Cl}=$ cochlear implant; $\mathrm{REVT}=$ Receptive Expressive Vocabulary Test (Kim, Hong, Kim, Jang, \& Lee, 2009); EA = equivalent age; $\mathrm{EA}-\mathrm{CA}=$ difference between $\mathrm{EA}$ and $\mathrm{CA} ; \mathrm{EA}-\mathrm{HA}=$ difference between $\mathrm{EA}$ and $\mathrm{HA}$. ${ }^{* *} p<.01$.
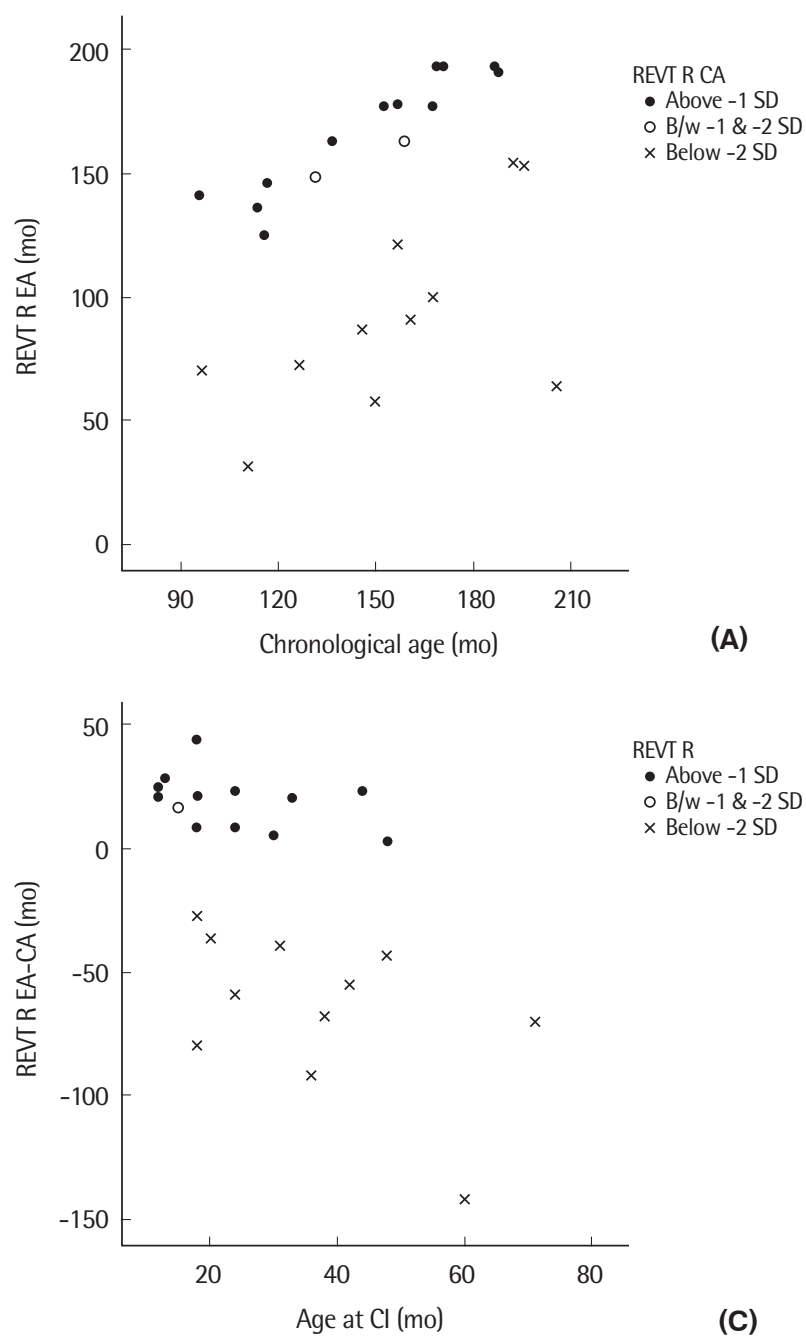

전체 집단의 $\mathrm{EA}-\mathrm{HA}$ 평균은 $12.36(\mathrm{SD}=41.94)$ 개월이었으며, 듣기 연령보다 등가월령이 낮은 집단에서 EA-HA의 범위는 -82부터 -8 개월이었다. Figure 2D에서 REVT-R EA-HA가 0 이하인 대상자는 모두 ‘어휘능력 발달지체’ 집단에 속하는데, 그림의 산포도는 연구 대상자의 어휘발달 지체 정도가 인공와우 수술시기나 듣기연령의 증가와 상관관계가 없음을 보여준다 $(r=-.227, p=.274)$.

\section{말지각 검사 결과}

검사대상자의 DASP SCT, SRT, CST 결과는 각각 Figures 3-5에 제시하였다. 각 그림의 $(\mathrm{A})$ 는 생활연령에 따른 정반응률을, $(\mathrm{B})$ 는 듣기연령에 따른 정반응률을 나타낸다. 각 그림은 어휘발달 정상성 판단 결과와 인공와우 이식연령을 구분하여 말지각 수행 결과를
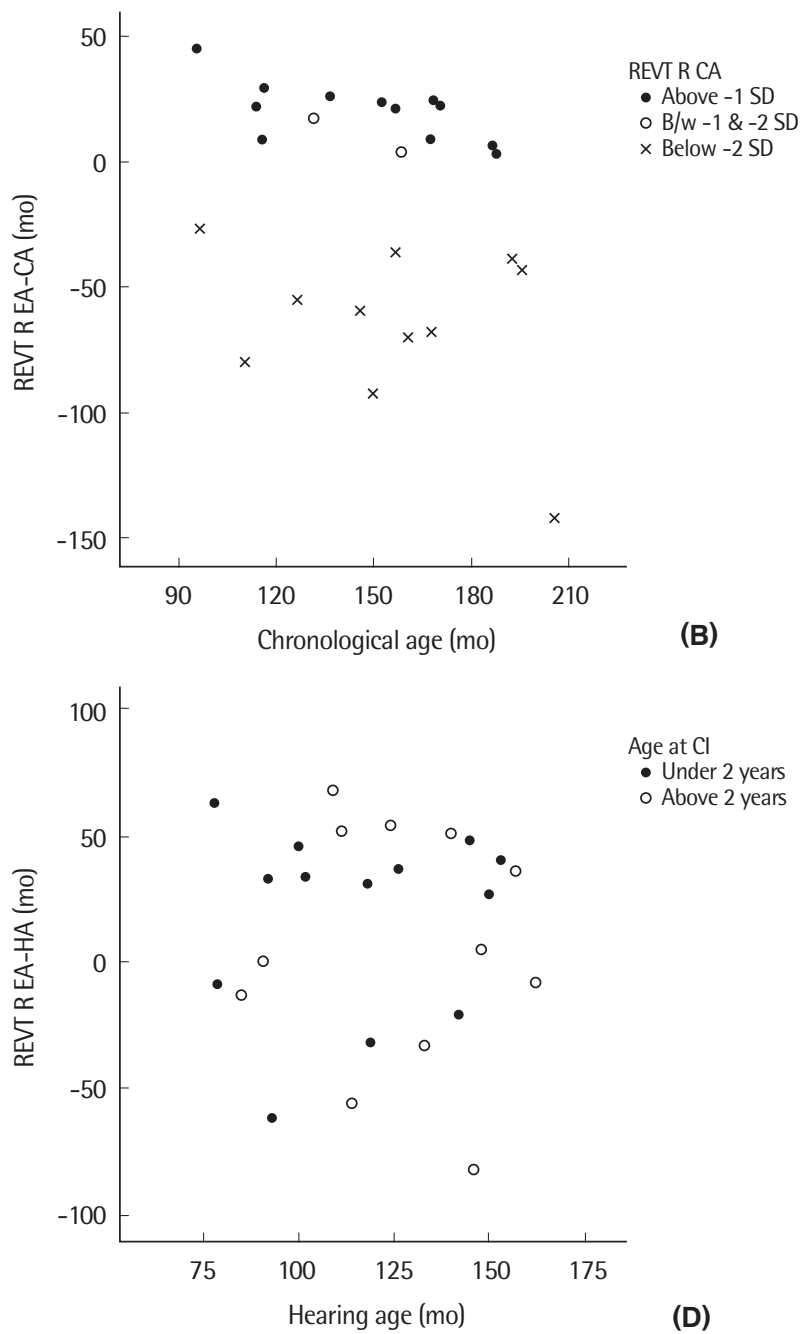

Figure 2. REVT_receptive equivalent age scores and the difference from the norm of REVT as a function of chronological age (A-C) and hearing age (D). REVT=Receptive \& Expressive Vocabulary Test (Kim, Hong, Kim, Jang, \& Lee, 2009); EA= equivalent age; $C A=$ chronological age; $H A=$ hearing age; EA-CA=difference between $\mathrm{EA}$ and $\mathrm{CA} ; \mathrm{EA}-\mathrm{HA}=$ difference between $\mathrm{EA}$ and $\mathrm{HA} ; \mathrm{Cl}=$ cochlear implant. 

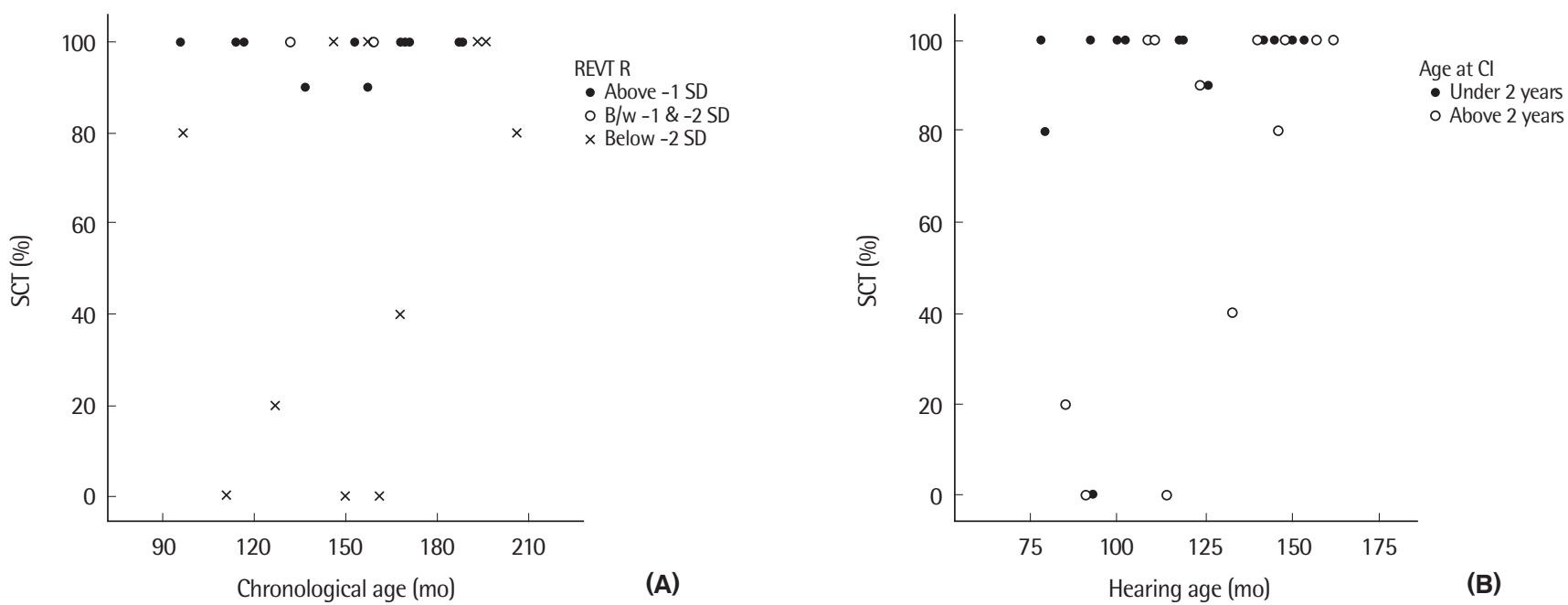

Figure 3. Sentence Comprehension Test (SCT) scores as a function of (A) chronological age and (B) hearing age. Filled dots indicates the group that implanted their $\mathrm{Cl}$ at under 2 years of age, and the transparent circle indicates the group that implanted their $\mathrm{Cl}$ at above 2 years of age. REVT=Receptive Expressive Vocabulary Test (Kim, Hong, Kim, Jang, \& Lee, 2009); Cl= cochlear implant.
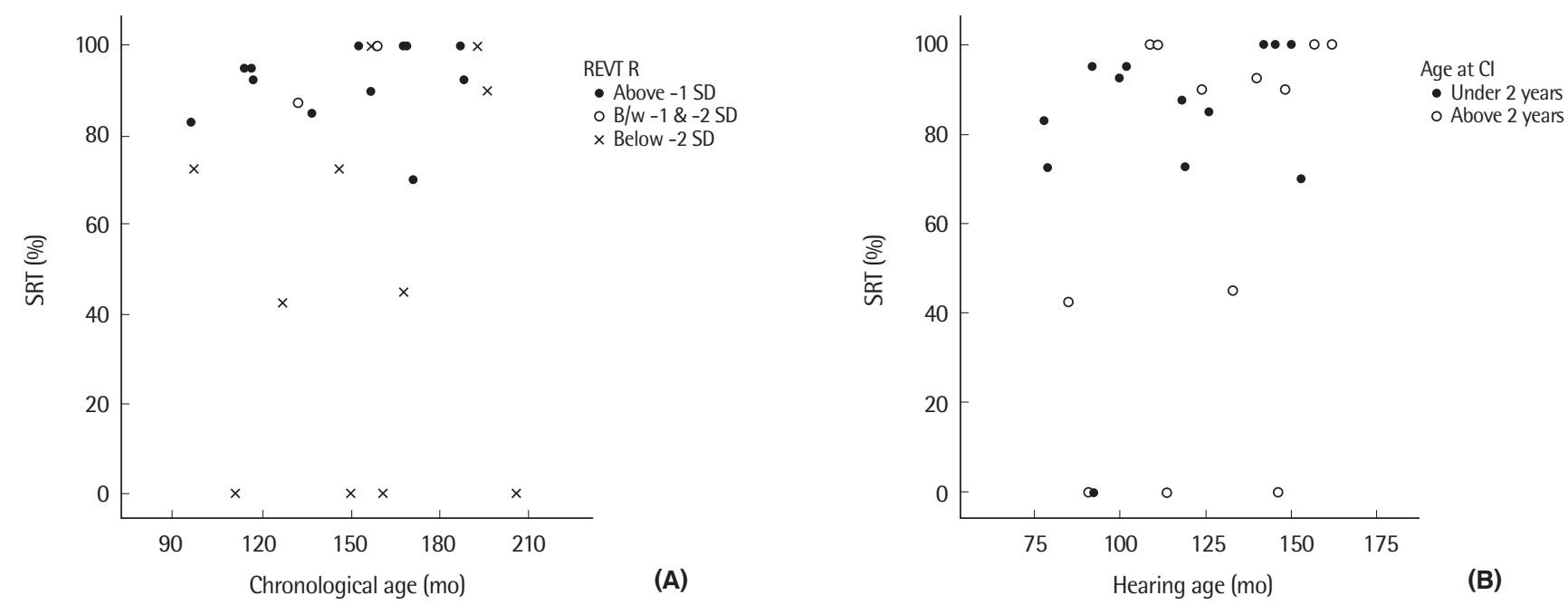

Figure 4. Sentence Recognition Test (SRT) scores as a function of (A) chronological age and (B) hearing age. Filled dots indicates the group that implanted their Cl at under 2 years of age, and the transparent circle indicates the group that implanted their $\mathrm{Cl}$ at above 2 years of age. REVT=Receptive Expressive Vocabulary Test (Kim, Hong, Kim, Jang, \& Lee, 2009); Cl= cochlear implant.

표시하였으며, 각 검사 집단의 평균 및 표준편차는 Table 3에, 말지 각 검사와 연령 관련 변인과의 상관관계는 Table 4에 제시하였다. 세가지 검사 모두 정반응률은 $0 \%-100 \%$ 였다.

문장을 듣고 대답하게 하는 방식으로 문장수준 말지각 능력을 검사한 SCT의 정반응 평균은 $80.00 \%(\mathrm{SD}=35.94 \%)$ 였다. 25 명의 연구대상자 중 16 명(64\%)이 $100 \%$ 의 정반응률을, 5 명(20\%)이 $50 \%$ 미만의 정반응률을 나타내었다. 초등학교와 중고등학교 학생의 SCT 평균점수는 각각 $74.17 \%$ 와 $85.38 \%$ 로 통계적으로 유의한 차 이가 없었다 $(t(23)=-.773, p=.447)$. REVT의 정상성 판단 결과에
따라 SCT 수행점수를 살펴본 결과, 어휘력 정상발달 집단에 속한 연구대상자 12 명 중 10 명(83.3\%)이 생활연령에 관계없이 SCT에서 $100 \%$ 의 수행을 보인 반면, 어휘력 발달지체 집단에 속한 검사대상 자는 11 명 중 2 명(18.2\%)의 아동만이 $100 \%$ 의 수행을 보였다. 어휘 력 정상발달 집단과 어휘력 지체 집단(약간 지체 및 발달지체)의 SCT 평균점수는 각각 98.33\%와 63.08\%로 통계적으로 유의한 차 이를 보였다 $(t(23)=2.770, p=.011)$. 듣기연령 78 개월 이상에서 인공 와우 이식 시기가 2 세 이전인 13 명의 검사대상자 중 10 명(76.9\%)이, 2 세 이후인 12 명 중 6 명(50\%)이 듣기연령에 관계없이 $100 \%$ 의 수행 

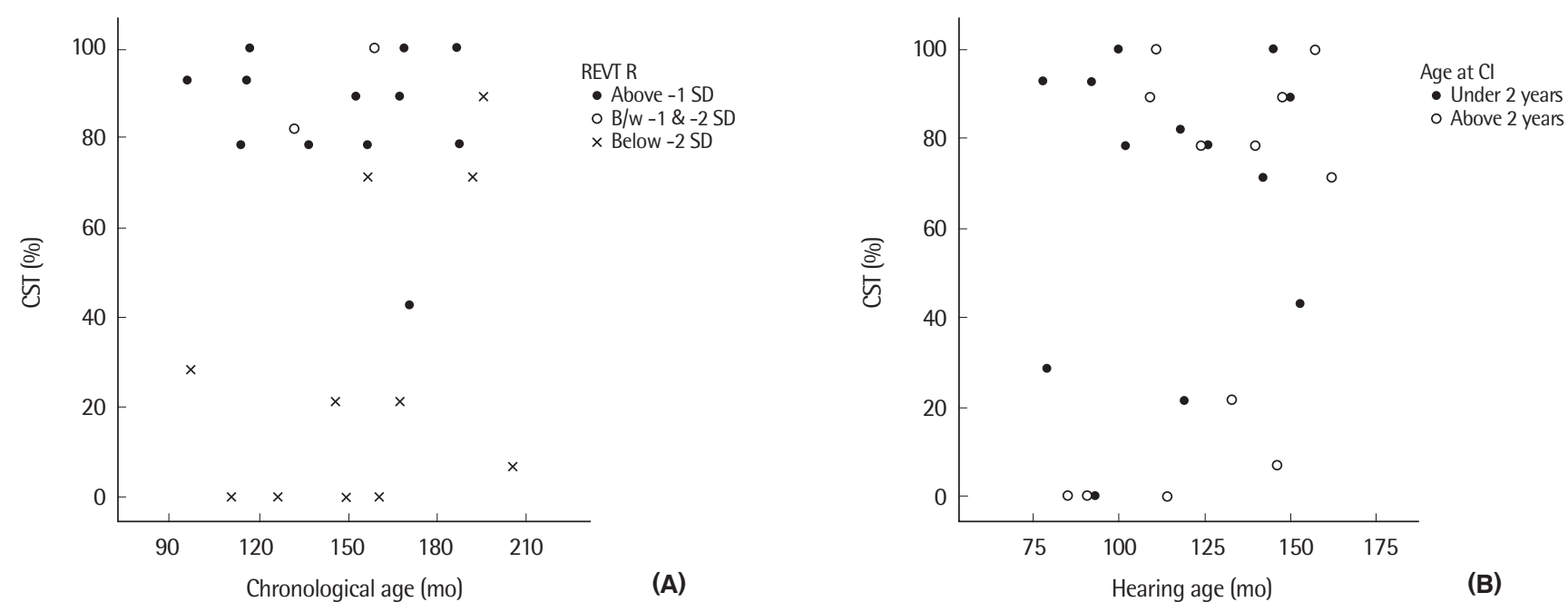

Figure 5. Connected Speech Test (CST) scores as a function of (A) chronological age, and (B) hearing age. Filled dots indicates the group that implanted their Cl at under 2 years of age, and the transparent circle indicates the group that implanted their $\mathrm{Cl}$ at above 2 years of age. REVT=Receptive Expressive Vocabulary Test (Kim, Hong, Kim, Jang, \& Lee, 2009); Cl= cochlear implant.

Table 3. Results of mean (SD) of SCT, SRT, and CRT

\begin{tabular}{|c|c|c|c|c|c|c|}
\hline & \multicolumn{2}{|c|}{ School } & \multicolumn{2}{|c|}{ Vocabulary } & \multicolumn{2}{|c|}{ Age at $\mathrm{Cl}$} \\
\hline & Elementary & Secondary & Normal & Delay & Before 2 years & After 2 years \\
\hline SCT & $74.17(41.44)$ & 85.38 (30.72) & 98.33 (3.89) & $63.08(43.85)$ & 90.00 (27.69) & 69.17 (41.66) \\
\hline SRT & 68.79 (35.56) & 75.96 (37.27) & $91.92(9.01)$ & 54.62 (42.15) & $81.00(26.61)$ & 63.33 (43.12) \\
\hline CST & 55.37 (41.37) & 65.39 (35.68) & $85.15(15.86)$ & $37.90(38.76)$ & 67.61 (33.11) & 52.97 (42.90) \\
\hline
\end{tabular}

SCT = Sentence Comprehension Test; $\mathrm{SRT}=$ Sentence Recognition Test; CST = Connected Speech Test; $\mathrm{Cl}=$ cochlear implant.

Table 4. Correlations between age factors and speech perception scores

\begin{tabular}{lcccccc}
\hline & CA & HA & Age at Cl & SCT & SRT & CST \\
\hline CA & - & $.863^{* *}$ & $.569^{* *}$ & .151 & .011 & .045 \\
$\mathrm{HA}$ & & - & .079 & .390 & .271 & .252 \\
Age at Cl & & & - & -.356 & $-.427^{*}$ & -.332 \\
\hline
\end{tabular}

$\mathrm{CA}=$ chronological age; $\mathrm{HA}=$ hearing age; $\mathrm{Cl}=$ cochlear implant; $\mathrm{SCT}=$ Sentence Comprehension Test; SRT = Sentence Recognition Test; CST = Connected Speech Test. ${ }^{*} p<.05,{ }^{* *} p<.01$.

을 보였다. 인공와우 이식연령이 2세 이전인 집단과 2세 이후인 집 단의 평균 점수는 각각 $90.00 \%$ 와 $69.17 \%$ 이나 집단간 차이는 통계 적으로 유의하지 않았다 $(t(23)=1.484, p=.151)$. 상관분석 결과 듣 기연령은 SCT 검사 결과와 유의한 관계를 보이지 않았다 $(r=.390$, $p=.054)$.

문장을 듣고 따라하는 방식으로 문장수준 말지각 능력을 검사 한 SRT의 정반응률 평균은 $72.52 \%(\mathrm{SD}=35.88 \%)$ 였으며, 전체 25 명 중 $100 \%$ 4명을 포함하여 20 명(80\%)이 $70 \%$ 이상을, $0 \% 4$ 명을 포 함한 5명(20\%)이 50\% 미만의 점수를 나타내었다. 초등학교와 중고 등학교 학생의 SRT 평균점수는 각각 $68.79 \%$ 와 $75.96 \%$ 로 통계적으
로 유의한 차이가 없었다 $(t(23)=-.491, p=.628)$. 참여자 중 7명 $(28 \%)$ 은 SRT에서 $100 \%$ 의 정반응을 보였는데, 어휘력 정상발달 집단에 속한 대상자가 4명(33.3\%), 약간 지체 및 어휘력 발달지체 집단에 속한 대상자가 3 명(23.1\%)이었다. 어휘력 정상발달 집단이 어휘력 지체 집단보다 통계적으로 유의하게 높은 SRT 평균점수를 보였다 $(t(23)=2.998, p=.006)$. Figure 4의 산포도에서 알 수 있듯이 SRT 에서 $100 \%$ 수행을 보인 대상자와 $0 \%$ 의 수행을 보인 대상자는 생 활연령 및 듣기연령에 관계없이 고르게 분포하고 있으나 인공와우 이식연령으로 나눈 집단별 수행을 살펴보았을 때 서로 다른 양상 을 보였다. 인공와우 이식연령이 2 세 이전인 대상자 13 명 중 12 명 (92.3\%)이 SRT에서 $70 \%$ 이상, 1 명(7.7\%)이 $0 \%$ 의 정반응을 보인 반 면, 2 세 이후 집단 12 명 중 7 명(58.3\%)은 $90 \%$ 이상의 정반응을, 5 명 (41.7\%)은 $50 \%$ 이하의 수행을 보였다. 2 세 이전 인공와우 시술 집단 과 2세 이후 인공와우 시술 집단의 수행력은 각각 $81.00 \%$ 와 $63.33 \%$ 이었으나, 집단간차이는 통계적으로 유의하지 않았다 $(t(23)=1.244$, $p=.226)$. 그러나 상관분석 결과 인공와우 이식연령은 SRT 수행과 유의한 관계가 있는 것으로 나타났다 $(r=-.427, p=.033)$. 즉, 인공와 

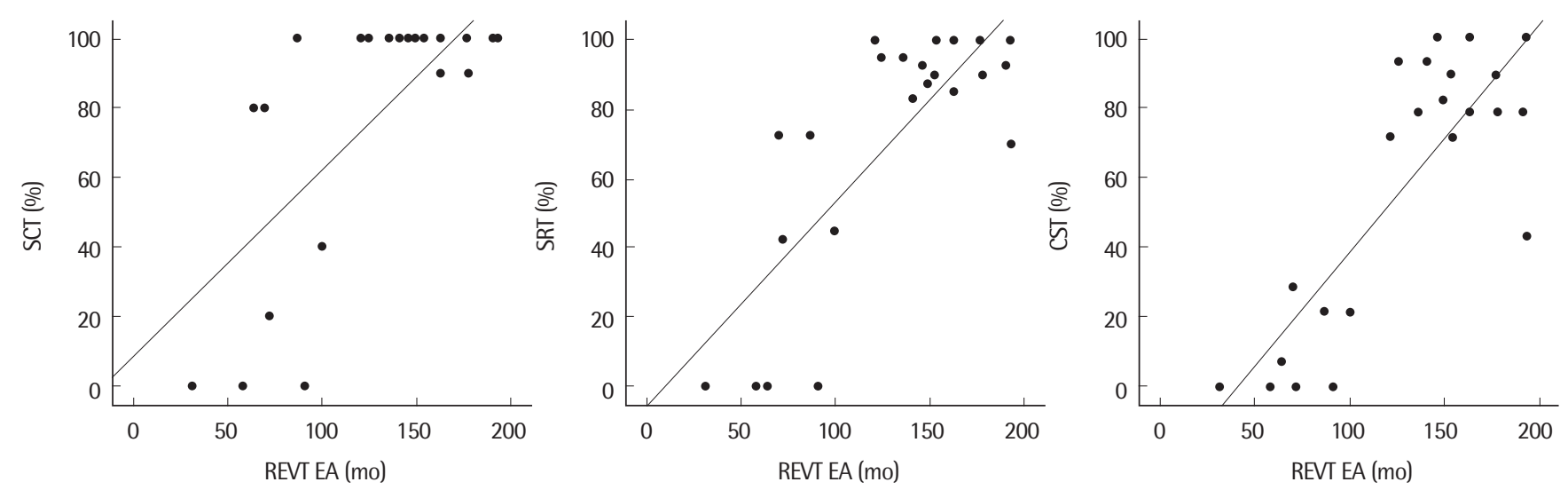

Figure 6. Speech perception scores as a function of the vocabulary score. REVT=Receptive Expressive Vocabulary Test (Kim, Hong, Kim, Jang, \& Lee, 2009); EA=equivalent age; SCT = Sentence Comprehension Test; SRT = Sentence Recognition Test; CST = Connected Speech Test.

우 이식연령이 높아질수록 SRT의 수행력이 유의미하게 낮아짐을 알수 있다.

이야기를 듣고 그 내용에 대한 질문에 답하는 방식으로 담화 수 준의 말지각 능력을 검사한 $\mathrm{CST}$ 의 정반응률 평균은 $57.01 \%(\mathrm{SD}=$ $39.40 \%$ )였으며, 전체 25 명 중 $100 \%$ 3명을 포함하여 16 명(64\%)이 $70 \%$ 이상을, $0 \% 4$ 명을 포함한 9 명 $(36 \%)$ 이 $50 \%$ 미만의 점수를 나타 내었다. 초등학교와 중고등학교 학생의 CST 평균점수는 각각 $55.37 \%$ 와 $65.39 \%$ 로 중고등학교 학생의 점수가 높았으나 통계적으로 유의 한 차이는 없었다 $(t(23)=-.650, p=.522)$. REVT 결과 어휘력 정상 발달 집단과 지체 집단의 수행은 각각 $85.15 \%$ 와 $37.90 \%$ 로 어휘력 정상발달 집단의 점수가 유의하게 높았다 $(t(23)=3.925, p=.001)$ 인공와우 이식연령이 2 세 이전인 집단과 2 세 이후인 집단간 CST 평 균점수는 각각 $67.61 \%$ 와 $52.97 \%$ 로 2세 이전 집단의 점수가 높았으 나 통계적으로는 유의한 차이가 없었으며 $(t(23)=.960, p=.347)$, 인 공와우 이식연령이 2 세 이전인 대상자 중 4 명 $(30.8 \%)$ 과 2 세 이후인 대상자 5명(41.7\%)이 CST에서 50\% 미만의 점수를 보여 이식 연령 에 상관없이 담화 수준에서의 말지각 처리에 어려움을 보였다. Figure 5는 생활연령이나 듣기연령에 관계없이 SCT의 수행 정도가 다 양하게 분포하고 있음을 나타내며, 상관분석 결과 SCT의 수행은 연령 변인과 유의미한 관계가 없었다( $p>.05)$.

\section{어휘력과 말지각 상관성}

REVT 등가월령과 SCT, SRT, CST와의 관계를 알아보기 위해 상 관분석을 실시하였으며 그 결과를 Figure 6과 Table 5에 제시하였다. REVT 등가월령은 문장 수준의 말지각 능력인 SRT 및 SCT와 각각 .797 ( $p$ <.0001), .731 ( $p<.0001)$ 로 유의미한 상관관계가 있었으며, 담화 수준의 말지각 능력과 가장 높은 상관 $(r=.836, p<.0001)$ 이
Table 5. Correlations between vocabulary and speech perception test scores

\begin{tabular}{lcccc}
\hline & REVTEA & SRT & SCT & CST \\
\hline REVT EA & - & $.797^{* *}$ & $.731^{* *}$ & $.836^{* *}$ \\
SRT & & - & $.871^{* *}$ & $.898^{* *}$ \\
SCT & & & - & $.814^{* *}$ \\
CST & & & & - \\
\hline
\end{tabular}

REVT = Receptive Expressive Vocabulary Test (Kim, Hong, Kim, Jang, \& Lee, 2009); $E A=$ equivalent age; SCT = Sentence Comprehension Test; SRT = Sentence Recognition Test; CST $=$ Connected Speech Test. ${ }^{* *} p<.01$

있는 것으로 나타났다. 또한 문장 수준의 말지각 능력인 SRT, SCT 는 모두 담화 수준의 말지각 능력인 CST와 각각 .898 ( $p$ <.0001)와 .814 ( $p$ <.0001)의 유의하게 높은 상관이 있는 것으로 나타났다.

\section{논의 및 결론}

본 연구에서는 선천적인 청각장애를 가지고 태어나 12-71개월 사이에 인공와우를 시술받고 6년 6개월 이상 인공와우를 사용하 고 있으며 일반 초등 및 중고등학교에서 통합교육을 받고 있는 인공 와우 사용자 25 명을 대상으로 수용어휘와 문장 및 담화 수준에서 의 말지각 능력, 그리고 어휘력과 말지각 능력 간의 상관관계를 살 펴보았다.

어휘력 평가 결과 연구대상자 중 생활연령 기준 $48 \%$, 듣기연령 기준 $56 \%$ 는 REVT 규준의 정상발달 범위에 해당하는 어휘력을 가 진 것으로 나타났다. 이러한 결과는 5 세 이전에 인공와우를 시술한 $5-13$ 세 학령기 인공와우 착용 아동의 $50 \%-57 \%$ 가 건청인 또래의 평균 범위에 속한다는 Boons 등(2013)과 Geers 등(2009)의 연구 결 과와 일치한다. 원점수를 등가월령으로 환산하여 어휘력의 지체 정 
도를 분석한 결과 인공와우 사용자 집단의 평균 어휘력은 생활연 령을 기준으로 한 검사규준보다 약 1년 6개월 지체되는 것으로 나 타났으나, 듣기연령을 기준으로 했을 때에는 집단 평균이 검사 규 준보다 약 12 개월 상회하였다. 또한 상관분석 결과에서도 연구대상 자의 어휘력이 생활연령이 아닌 듣기연령, 즉 인공와우를 사용하여 말소리를 경험한 기간과 유의한 관계가 있는 것으로 나타났다. 이 러한 결과는 인공와우 착용 아동들의 언어발달이 집단 평균에서 듣기연령과 생활연령을 일치시킨 아동의 정상발달 범위에 해당하 며, 언어능력이 청각적 정보를 접한 기간에 비례하여 발달한다는 선행연구 결과와 일치한다(Fagan \& Pisoni, 2010; Thal et al., 2007).

어휘력과 연령 관련 변인과의 상관분석 결과는 생활연령이 같은 규준과 비교했을 때 인공와우를 시술한 연령이 늦을수록 어휘력 이 지체되는 정도가 더 크고, 듣기연령이 같은 규준과 비교했을 때 어휘발달의 정상성 여부는 인공와우 이식연령이나 듣기연령에 관 계없는 것으로 나타났다. 이러한 상관분석 결과를 종합하면 일반 적으로 인공와우 착용 아동의 어휘력이 듣기경험에 비례해 발달하 며, 인공와우를 시술한 나이가 어릴수록 생활연령을 기준으로 한 정상발달 범주에 속할 가능성이 크지만, 듣기연령이 같은 규준과 비교했을 때 인공와우 이식연령이나 듣기연령에 관계없이 언어능 력 발달지체가 나타날수 있음을 의미한다.

본 연구의 대상자 중 생활연령 기준 $44 \%$, 듣기연령 기준 $32 \%$ 는 $\mathrm{REVT}$ 규준보다 $-2 \mathrm{SD}$ 이상 어휘력이 지체되는 것으로 확인되었는 데, Figure 2의 (C)에서 알 수 있듯이 이들의 수술 시기는 18-71개월 로 넓은 분포를 보여 인공와우 이식연령, 즉 청각적으로 정보를 접 하기 시작한 시기와 듣기 경험 이외에 다른 변인의 영향이 있음을 드러내고 있다. 동일한 조건의 인공와우 착용 아동들 간에 어휘량 이나 어휘 습득 속도 등 어휘력 발달에 개인차가 있다는 것은 여러 선행연구를 통해 보고된 결과로(Geers et al., 2009; Hawker et al., 2008; Hayes et al., 2009; Svirsky, Stallings, Lento, Ying, \& Leonard, 2002), 최근 청각장애 발견시기, 인공와우 이식연령과 듣기연령, 재 활 시작 시기와 함께 아동 개인이 가진 언어인지적 정보처리 능력 과 학습능력 등이 어휘력 발달의 개인차를 유발하는 기저 변인일 수 있음이 보고되고 있다(Pisoni \& Cleary, 2004). 본 연구에서는 연 령 관련 변인만이 고려되었으며, 향후 연구에서 보다 많은 표본을 통해 청각장애 발견 시기나 재활여부 등이 언어발달에 미치는 영 향을 확인해야 할 필요가 있다. 그럼으로써 청각장애 아동의 언어 중재에서 언어발달 지체와 관련된 기저변인을 고려하여 촉진하는 방향으로 나아가야 할 것이다.

연구대상자들은 말지각 평가 과제에서도 다양한 수행결과를 보 였다. DASP의 SCT, SRT, CST 말지각 과제의 수행범위는 모두 0\%-
$100 \%$ 에 이르기까지 다양하게 나타났는데, SCT, SRT, CST에서 각 각 $64 \%, 28 \%, 16 \%$ 의 참가자만이 $100 \%$ 의 말지각 수행을 보였고, 각 과제에서 $0 \%$ 를 보인 아동도 3-4명에 이른다. 정상청력 아동을 대상 으로 한 DASP의 표준화 연구에서 초등학교에 1-3학년에 재학하는 학령기 아동들이 세 검사에서 평균 $100 \%$ 의 정반응을 보인 것을 고 려할 때, 청각장애가 있는 아동들이 정상청력 또래에 필적할만한 어휘력과 인공와우를 통해 최소한 6년 6개월 이상의 청각정보를 접한 경험이 있는 경우에도 문장 및 담화 수준의 청각적인 정보처 리에 어려움이 있을 수 있으며, 문장보다는 담화 수준에서, 즉 청각 적으로 처리해야 하는 정보의 양이 많아질수록 그 수행이 더 어렵 다는 사실을 보여준다. 어휘력 발달유무, 2 세 이전과 이후의 인공 와우 이식연령, 초등 및 중고등학교를 변인으로 집단간 차이를 분 석한 결과 어휘력 정상발달 집단과 지체 집단 간의 말지각 수행 차 이는 유의하였으나, 인공와우 이식연령 차이와 초등 및 중고등학생 사이의 수행 차이는 유의하지 않았다. 특히 듣기를 통하여 많은 정 보를 수용해야 하는 중고등학교 학생들조차도 말지각 검사의 수행 력이 초등학교 학생들과 유의미한 차이가 나타나지 않았다는 점은 우리에게 시사하는 바가 크다.

본 연구에서 나타난 문장 및 담화수준의 수행 결과는 두 가지로 생각해 볼 수 있다. 첫째, 구문능력의 영향이다. 본 연구는 통합교육 환경에 있는 인공와우 착용 아동들의 말지각 능력의 현황을 파악 하고자 구문능력을 평가하거나 제한하지 않았다. 따라서 구문적인 능력이 떨어져도 내용어를 기반으로 문장 수준의 정보를 처리할 수 있는 아동들이 대상에 포함되었을 수 있다. SCT와 SRT의 수행 차이가 이를 반영하는 것으로 여겨진다. SCT 과제가 문장 수준의 청각정보를 이해하여 단답형으로 대답할 것을 요구한 반면, SRT 과제는 문장 수준의 청각정보를 그대로 따라 말하도록 요구하는 문장 따라말하기 과제로 두 방법 모두 문장 수준의 말지각을 검사 하는 데 널리 쓰이고 있다. 특히 문장 따라말하기는 Bamford-Kowal-Bench (BKB) Sentence (Bamford \& Wilson, 1979) 등 보기가 없 는 조건의 문장인지 검사에서 가장 많이 쓰이는 방법이다. 그러나 다른 한편 문장 따라말하기 과제는 구문능력과 상관이 있어서, 정 상발달 및 언어장애 아동 집단에서 그 실수가 구문발달을 반영하 는 것으로 확인되어(Riches, 2012) 오랫동안 언어장애 아동들의 임 상적 지표로 사용되고 있다(Bishop, North, \& Donlan, 1996; Conti-Ramsden, Botthing, \& Faragher, 2001; Stokes, Wong, Fletcher, \& Leonard, 2006). 또한 문장 따라말하기의 어려움은 언어적 정보 처리의 어려움과 관련된 것으로 알려져 있다(Conti-Ramsden et al., 2001). 따라서 SCT에 비해 SRT 과제에서 어려움을 보이는 아동 이 증가한 것은 본 연구대상자들의 말지각 능력뿐 아니라 구문 발 
달 또는 언어적 정보처리의 어려움이 반영된 결과일 수 있다. 담화 수준의 말지각을 평가한 CST에서 많은 대상자가 어려움을 보인 것 또한 이들의 담화 수준 청각정보 처리 능력의 한계를 반영할 뿐 아 니라 SRT에서 드러난 구문적인 한계로 인한 언어적 정보처리의 어 려움을 반영한 것일 수 있다.

둘째, 문장 및 담화 수준에서 말지각의 어려움은 이러한 구문적 인 어려움 외에 의사소통 기회의 제한과 원거리 우연듣기(overhearing)의 한계로 인한 문장 및 담화 수준에서 말지각 처리 경험 부족 이 정보처리에 필요한 인지적 능력 발달에 영향을 미친 결과일 수 있다. SCT, SRT, CST는 공통적으로 들은 것을 기억하고 그 내용을 파악하여 과제의 요구에 적절하게 반응하는 능력을 필요로 하여, 청각적인 정보의 탐지 및 작업기억, 구두적 시연(verbal rehearsal) 능력을 필요로 한다. 학령기 청각장애 아동을 대상으로 한 선행연 구는 인공와우를 사용한 청각장애 아동들이 작업기억과 청각적 정보처리 속도에서 건청 아동보다 지체된 수행 및 발달을 보인다고 보고하고 있는데(Pisoni \& Cleary, 2004; Pisoni et al., 2011), 이렇게 지체된 작업기억 능력과 정보처리 속도로 인해 말소리 정보를 처리 하는 데 어려움이 발생한 것일 수 있으며, 이로 인해 문장보다 더 많 은 정보를 담고 있는 담화 수준에서 더 큰 어려움을 나타낸 것일 수 있다. 이러한 결과는 인공와우 착용 아동을 대상으로 한 재활에서 청각적 정보처리와 관련된 인지적 능력의 발달을 촉진하기 위해 문 장 및 담화 수준에서의 청각적 정보처리 경험을 증가시킬 수 있는 접근 방법과 내용이 고려되어야 함을 시사한다.

문장 및 담화 수준의 말지각 수행 능력과 연령 관련 변인들과의 관계는 과제마다 다소 다르게 나타났다. SRT 결과가 인공와우 이식 연령과 반비례 관계에 있고 SCT 결과와 듣기연령과의 관계는 유의 수준에 근접하게 나타났으나, 이를 제외한 말지각 수행은 인공와 우 이식 연령이나 듣기연령과 관계가 없었다. Figures 3-5의 (A)에서 알 수 있듯이 생활연령 또한 말지각 능력과 유의한 관계가 없었는 데, 이는 언어능력이 말지각 능력 평가에 미치는 영향을 최소화한 준거참조 평가라는 DASP의 특성을 고려할 때, 검사대상자의 연령 보다는 다른 변인들이 말지각에 미치는 영향이 반영된 결과로 생 각된다. SRT와 인공와우 이식연령과의 상관관계는, 위에서 언급하 였듯이 SRT 과제가 말지각 외에 아동들의 구문 및 인지능력을 필 요로 하고, 수술 연령이 어릴수록 어휘력이 정상발달 범주에 해당 하도록 발달할 수 있기 때문에, 수술 연령이 어릴수록 SRT 형식의 말지각 과제 수행에 필요한 어휘, 구문 및 인지 능력 발달이 촉진될 수 있음을 반영하는 것으로 생각된다. 그러나 인공와우 이식연령 을 기준으로 한 집단 간 차이가 유의하지 않고, Figures 3-5의 (B)에 서 확인할 수 있듯이 2 세 이후에 수술한 아동 다수가 SCT 및 SRT
과제에서 좋은 수행을 보이고 있고, SRT 과제에서 좋은 수행을 보 인 아동들이 더 많은 정보처리 능력을 요구하는 CST 과제에서 어 려움을 보이며, CST 과제가 연령 변인과 유의한 상관관계가 없었 다는 점을 고려하여, 본 연구에서 나타난 수술 시기와 SRT 과제의 관계를 문장 및 담화 수준의 말지각 발달 전체로 일반화하여 해석 할 수 없다는 점에 주의해야 할 것이다. 5 세 이전에 인공와우를 시 술하고 3 년 이상 기기를 사용한 초등학교 아동들에게서 말지각과 인공와우 이식연령에 유의한 관계가 없었다는 선행연구를 고려할 때(Heo et al., 2011), 본 연구에서 SCT나 CST 등의 말지각 과제에 서 시술연령과 상관관계가 나타나지 않은 것은 본 연구대상자들의 인공와우 사용경험이 6년 6개월 이상으로, DASP의 말지각 검사 일 부에서 시술연령이 그 결과에 미치는 영향에 고원현상이 나타난 때문인 것으로 생각된다.

인공와우 이식연령이나 듣기연령은 말지각 능력과의 상관관계 가 유의하지 않았으나 어휘력은 문장 및 담화 수준의 말지각 능력 모두와 유의하게 높은 상관관계가 있었다. 이는 말소리 지각 능력 이 언어능력과 서로 상관관계가 있으며 문장 수준의 말지각 수행력 이 언어능력의 발달을 반영한다는 선행연구와 일치하는 결과로 Blamey 등(2001)의 연구에서는 어휘력검사(PPVT)의 등가연령 7 세, Davidson 등(2011)의 연구에서는 어휘력검사의 등가연령 10세 까지 말지각 수행력이 어휘력에 따라 증가한다고 하였다. 본 연구에 서도 말지각 수행력이 어휘력에 따라 상이한 것으로 나타났는데, SCT 과제는 REVT 등가월령 87개월(7;3세), SRT 과제는 REVT 등 가월령 121 개월(10;1세), 그리고 CST 과제는 REVT 등가월령 125 개월(10;5세) 이상에서 대부분의 연구대상자가 $90 \%$ 이상의 수행 을 보여서, 말지각 과제의 성격에 따라 고원현상에 이르는 연령이 다르게 나타났다. 그러나 문장을 듣고 답하는 SCT과제는 REVT 등가월령 7;3세, 문장 전체를 따라 말하는 SRT과제는 10;1세에 고 원현상이 나타나 문장단계에서 고원현상이 나타나는 연령이 앞서 인용한 선행연구와 거의 일치하는 결과를 보였다. CST와 같이 구 문이나 언어적 정보처리 능력 등 더 많은 언어능력을 요하는 과제 일수록 고원현상에 도달하는 연령이 높아진다는 점에서 말지각 과 제에서 어휘력 및 언어능력의 중요성을 확인할 수 있다.

본 연구에서 어휘력이 문장 및 담화 수준의 말지각 능력과 유의 하게 높은 상관관계를 보이는 것은 이 두 영역이 서로 밀접한 관련 이 있어 서로 영향을 주고받으며 발달하는 것임을 의미한다. 말지 각 능력이 어휘력을 반영하여 어휘력에 따라 향상되기도 하지만, 반대로 문장 및 담화 수준에서의 우수한 말지각 능력은 더 많은 의 사소통 기회와 우연학습의 기회를 제공함으로써 어휘력을 포함하 는 언어능력 향상에 큰 역할을 함을 알 수 있다. 그러므로 인공와우 
아동의 청각재활 목표는 문장 및 담화 수준의 말지각 능력과 어휘 력을 함께 향상시키는 것이어야 할 것이다.

본 연구 결과 4 명의 아동들은 문장 및 담화 수준에서 모두 $0 \%$ 이 거나 그에 가까운 수준을 보였다. 이 아동들의 자료를 보면 각각 18 , $36,60,71$ 개월에 인공와우를 이식했고, $91-146$ 개월의 인공와우 사 용 경험이 있으나 문장 수준의 말지각이 어려웠으며, 어휘력 또한 지체된 상태였다. 낮은 어휘력과 문장 지각력으로 또래와의 의사소 통은 물론 일반학교에서의 학습이 매우 어려울 것이라 예상되므로 개개인의 요구에 적합한 교육 지원과 재활 및 의사소통 방법이 강 구될 필요가 있다.

\section{REFERENCES}

Anderson, K. L. (2004). Auditory Skills Checklist. Available from http://successforkidswithhearingloss.com /wp-content/uploads/2011/12/AuditorySkills-Checklist-Cincinatti-Childrens-Hosp.pdf.

Bamford, J., \& Wilson, I. (1979). Methodological considerations and practical aspects of the BKB sentence lists. In R. J. Bench \& J. Bamford (Eds.), Speech-hearing tests and the spoken language of hearing-impaired children (pp. 148-187). New York: Academic Press.

Bishop, D. V., North, T., \& Donlan, C. (1996). Nonword repetition as a behavioural marker for inherited language impairment: evidence from a twin study. Journal of Child Psychology and Psychiatry, 37, 391-403.

Blamey, P. J., Sarant, J. Z., Paatsch, L. E., Barry, J. G., Bow, C. P., Wales, R. J., ... \& Tooher, R. (2001). Relationships among speech perception, production, language, hearing loss, and age in children with impaired hearing. Journal of Speech, Language, and Hearing Research, 44, 264-285.

Blamey, P., \& Sarant, J. (2002). Speech perception and language criteria for paediatric cochlear implant candidature. Audiology and Neurotology, 7, 114-121.

Blamey, P., Bow, C., Paatsch, L., Sarant, J., \& Galvin, K. (2004). Language outcomes for children with impaired hearing. Australian and New Zealand Journal of Audiology, 26(Supplement).

Boons, T., De Raeve, L., Langereis, M., Peeraer, L., Wouters, J., \& Van Wieringen, A. (2013). Expressive vocabulary, morphology, syntax and narrative skills in profoundly deaf children after early cochlear implantation. Research in Developmental Disabilities, 34, 2008-2022.

Cole, E. B., \& Flexer, C. (2015). Children with hearing loss: developing listening and talking, birth to six (3rd ed.). San Diego, CA: Plural Publishing.

Conti-Ramsden, G., Botting, N., \& Faragher, B. (2001). Psycholinguistic mark- ers for specific language impairment (SLI). Journal of Child Psychology and Psychiatry, 42, 741-748.

Convertino, C., Borgna, G., Marschark, M., \& Durkin, A. (2014). Word and world knowledge among deaf learners with and without cochlear implants. Journal of Deaf Studies and Deaf Education, 19, 471-483.

Davidson, L. S., Geers, A. E., Blamey, P. J., Tobey, E., \& Brenner, C. (2011). Factors contributing to speech perception scores in long-term pediatric CI users. Ear and Hearing, 32(1 Suppl), 19S-26S.

Duchesne, L., Sutton, A., \& Bergeron, F. (2009). Language achievement in children who received cochlear implants between 1 and 2 years of age: group trends and individual patterns. Journal of Deaf Studies and Deaf Education, 14, 465-485.

Erber, N. P. (1982). Auditory training. Washington, DC: Alexander Graham Bell Association for the Deaf and Hard of Hearing.

Fagan, M. K., \& Pisoni, D. B. (2010). Hearing experience and receptive vocabulary development in deaf children with cochlear implants. Journal of Deaf Studies and Deaf Education, 15, 149-161.

Geers, A. E., Moog, J. S., Biedenstein, J., Brenner, C., \& Hayes, H. (2009). Spoken language scores of children using cochlear implants compared to hearing age-mates at school entry. Journal of Deaf Studies and Deaf Education, 14, 371-385.

Hawker, K., Ramirez-Inscoe, J., Bishop, D. V., Twomey, T., O’Donoghue, G. M., \& Moore, D. R. (2008). Disproportionate language impairment in children using cochlear implants. Ear and Hearing, 29, 467-471.

Hayes, H., Geers, A. E., Treiman, R., \& Moog, J. S. (2009). Receptive vocabulary development in deaf children with cochlear implants: achievement in an intensive auditory-oral educational setting. Ear and Hearing, 30, 128135 .

Heo, M. J., Ahn, S. W., \& Boo, S. H. (2011). A path analysis of factors affecting the receptive vocabulary abilities of school-aged children with cochlear implants. Journal of Speech \& Hearing Disorders, 20, 149-173.

Holt, R. F., Beer, J., Kronenberger, W. G., Pisoni, D. B., \& Lalonde, K. (2012). Contribution of family environment to pediatric cochlear implant users' speech and language outcomes: some preliminary findings. Journal of Speech, Language, and Hearing Research, 55, 848-864.

Hyun, S. H., \& Yim, D. (2013). The performance on degraded listening task in children with cochlear implants. Communication Sciences \& Disorders, $18,86-97$.

Johnson, C., \& Goswami, U. (2010). Phonological awareness, vocabulary, and reading in deaf children with cochlear implants. Journal of Speech, Lan- 
guage, and Hearing Research, 53, 237-261.

Kang, J., \& Ha, S. (2013). The influential factors upon speech intelligibility of adolescents with cochlear implants. Communication Sciences \& Disorders, $18,318-329$.

Kaplan, H., Mahshie, J., Moseley, M. J., Singer, B., \& Winston, E. (1993). Research synthesis on design of effective media materials and technology for deaf and hard-of-hearing students. Eugene, OR: National Centre to Improve the Tools of Educators.

Kim, L. S., Lee, M. Y., Heo, M. J., \& Oh, Y. J. (2002). Long-term development of auditory performance in children with cochlear implants. Korean Journal of Otolaryngology-Head and Neck Surgery, 45, 18-21.

Kim, S. J., Kim, L. S., Cho, M. J., \& Rhee, K. S. (1998). Evaluation of speech perception abilities in children with cochlear implants. Korean Journal of Otolaryngology-Head and Neck Surgery, 41, 1391-1399.

Kim, Y. T., Hong, G. H., Kim, K. H., Jang, H. S., \& Lee, J. Y. (2009). Receptive \& expressive vocabulary test (REVT). Seoul: Seoul Community Rehabilitation Center.

Ling, D. (2002). Speech and the hearing-impaired child: theory and practice. Washington, DC: Alexander Graham Bell Association for the Deaf and Hard of Hearing.

Niparko, J. K., Tobey, E. A., Thal, D. J., Eisenberg, L. S., Wang, N. Y., Quittner, A. L., ... \& CDaCI Investigative Team. (2010). Spoken language development in children following cochlear implantation. Journal of the American Medical Association, 303, 1498-1506.

Perigoe, C. B., \& Paterson, M. (2013). Understanding auditory development and the child with hearing loss. In D. R. Welling \& C. A. Ukstins (Eds.), Fundamentals of audiology for the speech-language pathologist (pp. 173-204). Burlington, MA: Jones \& Bartlett Publishers.

Pisoni, D. B., \& Cleary, M. (2004). Learning, memory, and cognitive processes in deaf children following cochlear implantation. In F. G. Zeng, A. N. Popper, \& R. R. Fay (Eds.), Cochlear implants: auditory prostheses and electric hearing (pp. 377-426). New York: Springer.

Pisoni, D., Kronenberger, W., Roman, A., \& Geers, A. (2011). Article 7: Measures of digit span and verbal rehearsal speed in deaf children following more than 10 years of cochlear implantation. Ear and Hearing, 32, 60s-74s.

Quittner, A. L., Cruz, I., Barker, D. H., Tobey, E., Eisenberg, L. S., Niparko, J.
K., ... \& Childhood Development after Cochlear Implantation Investigative Team (2013). Effects of maternal sensitivity and cognitive and linguistic stimulation on cochlear implant users' language development over four years. Journal of Pediatrics, 162, 343-348.

Riches, N. G. (2012). Sentence repetition in children with specific language impairment: an investigation of underlying mechanisms. International Journal of Language \& Communication Disorders, 47, 499-510.

Romanik, S. (1994). Auditory Skills Program. (Master's thesis). University of Melbourne, Australia.

Song, Y. J., Lee, H. J., \& Jang, H. S. (2010). A study on the development of Korean National Institute of Special Education - Developmental Assessment of Speech Perception (KNISE-DASP) for auditory training. Special Education Research, 18, 3-167.

Stokes, S. F., Wong, A. M., Fletcher, P., \& Leonard, L. B. (2006). Nonword repetition and sentence repetition as clinical markers of specific language impairment: the case of Cantonese. Journal of Speech, Language, and Hearing Research, 49, 219-236.

Svirsky, M. A., Stallings, L. M., Lento, C. L., Ying, E., \& Leonard, L. B. (2002). Grammatical morphologic development in pediatric cochlear implant users may be affected by the perceptual prominence of the relevant markers. Annals of Otology Rhinology and Laryngology, 111(5 PART 2), 109-112.

Thal, D., DesJardin, J. L., \& Eisenberg, L. S. (2007). Validity of the MacArthur-Bates Communicative Development Inventories for measuring language abilities in children with cochlear implants. American Journal of Speech-Language Pathology, 16, 54-64.

Traxler, C. B. (2000). The Stanford Achievement Test, 9th edition: National norming and performance standards for deaf and hard-of-hearing students. Journal of Deaf Studies and Deaf Education, 5, 337-348.

Tye-Murray, N. (2014). Foundations of aural rehabilitation: children, adults, and their family members (4th ed.). Stamford, CT: Cengage Learningh.

Walker, B. (2009). Auditory learning guide (ALG). Chapel Hill, NC: First Years. Wu, C. M., Chen, Y. A., Chan, K. C., Lee, L. A., Hsu, K. H., Lin, B. G., ... \& Liu, T. C. (2010). Long-term language levels and reading skills in Mandarin-speaking prelingually deaf children with cochlear implants. Audiology and Neurotology, 16, 359-380. 


\section{국문초록}

\section{학령기 인공와우 착용 아동의 어휘력과 말지각 상관성}

박혜진 ${ }^{1}$ 한성아 ${ }^{1} \cdot$ 최재희 ${ }^{1} \cdot$ 심상용 ${ }^{1,2} \cdot$ 서영란 $^{3} \cdot$ 장현숙 $^{4}$

1한림대학교 일반대학원 언어병리청각학과, ${ }^{2}$ 다산 청능재활연구원, ${ }^{3}$ 경신 청각언어연구소, ${ }^{4}$ 한림대학교 언어청각학부

배경 및 목적: 본 연구는 학령기 인공와우 착용 아동의 생활연령 및 듣기연령에 따른 어휘력 발달 정도와 문장 및 담화 수준의 말지각 수행력, 그리고 말지각 수행력과 어휘력 간의 상관관계를 살펴보고자 하였다. 방법: 일반학교에서 통합교육을 받는 인공와우 착용 아 동 25 명(초등학생 12 명, 중고등학생 13 명)을 대상으로 하였다. 수용·표현어휘력검사(REVT)와 말지각 검사(DASP)의 문장이해(SCT), 문장인지(SRT), 이야기이해(CST)검사를 실시한 후 수용어휘력과 말지각 검사 결과의 상관분석을 통해 각 변인 간의 관계를 분석하였 다. 결과: 인공와우 착용 아동 집단의 평균 수용어휘력은 생활연령이 같은 건청 또래에 비해 약 1 년 6 개월 지체되었으나, 집단 평균은 듣 기연령이 같은 건청 아동의 수행 범위에 속하였다. 말지각 검사 결과는 검사연령 및 2 세를 전후로 한 인공와우 이식연령에 따른 차이가 없었으나, 어휘력 정상 집단과 지체 집단 사이에 유의한 차이가 있었으며, 어휘력은 문장 및 담화수준의 말지각 검사 수행력과 유의미하 게 높은 상관성을 보였다. 그러나 어휘력이 우수함에도 불구하고 문장 및 담화 수준의 말지각에서 어려움을 보이는 아동들이 있었다. 논의 및 결론: 인공와우 착용 아동들의 어휘력 수준은 듣기연령이 같은 건청 아동 수준을 보이나 여전히 지체를 보이고, 말지각 능력과 상관성을 보이므로 재활 시 문장 및 담화 수준에서 어휘능력 향상을 위한 재활지원이 필요하며, 개개인의 수준이 다양하므로 개별적 재활접근이 고려되어야 한다.

핵심어: 청각장애, 인공와우, 어휘력, 말지각, 문장이해, 문장인지, 이야기이해

\section{참고문헌}

강지송, 하승희(2013). 읽기이해부진아동의 단어유추를 통한 단어처리 특성. 언어청각장애연구, 18, 318-329.

김리석, 이미영, 허민정, 오영준(2002). 인공와우이식 아동의 장기간 청각 수행력의 발달. 대한이비인후과학회지, 45, 18-21.

김수진, 김리석, 조명준, 이규식(1998). 인공와우이식 아동들의 말인지력 평가. 대한이비인후과학회지, 41, 1391-1399.

김영태, 홍경훈, 김경희, 장혜성, 이주연(2009). 수용·표현어휘력검사(REVT). 서울: 서울장애인종합복지관.

송영준, 이효자, 장현숙(2010). 청능훈련을 위한 말지각 발달 검사 도구(KNISW-DASP)개발 연구. 특수교육연구, 18, 3-167.

허민정, 안성우, 부성현(2011). 학령기 인공와우이식 아동의 어휘이해력에 대한 경로모형 분석을 통한 관련변인 분석. 언어치료연구, 20, 149-173.

현승희, 임동선(2013). 인공와우이식 아동의 문맥조건에 따른 소음상황듣기 수행능력. 언어청각장애연구, 18, 86-97. 